\title{
Mercury in salt marshes ecosystems: Halimione portulacoides as biomonitor
}

\author{
M. Válega ${ }^{\mathrm{a}, *}$, A.I. Lillebø ${ }^{\text {a }}$, M.E. Pereira ${ }^{\text {a }}$, I. Caçador ${ }^{\text {b }}$, A.C. Duarte ${ }^{\text {a }}$, M.A. Pardal ${ }^{\mathrm{c}}$ \\ ${ }^{a}$ CESAM and Department of Chemistry, University of Aveiro, 3810-193 Aveiro, Portugal \\ ${ }^{\mathrm{b}}$ IO - Institute of Oceanography, Faculty of Sciences, University of Lisbon, Campo Grande, 1749-016 Lisboa, Portugal \\ ' IMAR - Institute of Marine Research, Department of Zoology, University of Coimbra, 3004-517 Coimbra, Portugal
}

\section{A R T I C L E I N F O}

\section{Article history:}

Received 18 April 2008

Received in revised form 15 July 2008

Accepted 20 July 2008

Available online 16 September 2008

\section{Keywords:}

Halimione portulacoides

Mercury

Salt marshes

Biomonitor

\begin{abstract}
A B S T R A C T
Mercury concentrations were quantified in Halimione portulacoides (roots, stems and leaves) as well as in sediments from eight Portuguese estuarine systems, covering seventeen salt marshes with distinct degrees of mercury contamination. The concentration of mercury in the sediments ranged from 0.03 to $17.0 \mu \mathrm{g} \mathrm{g}^{-1}$. The results show that the accumulation of mercury differed according to the organ of the plant examined and the concentration of mercury in the sediments. Higher mercury concentrations were found in the roots (up to $12.9 \mu \mathrm{g} \mathrm{g}^{-1}$ ) followed by the leaves (up to $0.12 \mu \mathrm{g} \mathrm{g}^{-1}$ ), while the stems had the lowest concentrations (up to $0.056 \mu \mathrm{g} \mathrm{g}^{-1}$ ). A linear model explained the relation between the concentrations of mercury in the different plant organs: roots and stems $\left(R_{\mathrm{adj}}^{2}=0.75\right)$, stems and leaves $\left(R_{\mathrm{adj}}^{2}=0.85\right)$ and roots and leaves $\left(R_{\mathrm{adj}}^{2}=0.78\right)$. However, the results show that the variation of mercury concentration in the roots versus mercury concentration in the sediments was best fitted by a sigmoidal model $\left(R_{\mathrm{adj}}^{2}=0.89\right)$. Mercury accumulation in the roots can be described in three steps: at a low range of mercury concentrations in the sediments (from 0.03 up to $2 \mu \mathrm{g} \mathrm{g}^{-1}$ ), the accumulation of mercury in roots is also low reaching a maximum concentration of $1.3 \mu \mathrm{g} \mathrm{g}^{-1}$; the highest rates of mercury accumulation in the roots occur in a second step, until the concentrations of mercury in the sediments reach approximately $4.5 \mu \mathrm{g} \mathrm{g}^{-1}$; after reaching this maximum value, the rate of mercury accumulation in the roots slows down leading to a plateau in the concentration of mercury in the roots of about $9.4 \mu \mathrm{g} \mathrm{g}^{-1}$, which corresponds to a mercury concentration in the sediments of about $11 \mu \mathrm{g} \mathrm{g}^{-1}$.

A linear model explained also the accumulation of mercury in leaves versus the mercury concentration in the sediments $\left(R_{\mathrm{adj}}^{2}=0.88\right)$. Differences in responses of roots and leaves are explained by the dynamics of the plant organs: old roots are mineralised in situ close to new roots, while leaves are renewed. Previous studies have already shown that $H$. portulacoides is a bioindicator for mercury and the results from this work sustain that $H$. portulacoides may also be used as a biomonitor for mercury contamination in salt marshes. Nevertheless, caution should be taken in the application of the models, concerning the life cycle of the species and the spatial variability of the systems.
\end{abstract}

(c) 2008 Elsevier Ltd. All rights reserved.

\section{Introduction}

Salt marshes are highly productive communities which provide several known ecological functions and represent an important habitat for a high number of estuarine and marine species with commercial value (Alongi, 1997). The high pressure caused by urban, industrial and agricultural development around coastal areas has increased the vulnerability of this ecosystem due to the exposure to both organic and inorganic contaminants from anthropogenic sources. In Portugal it is estimated by 2001 that $65 \%$ of the population lives in the coastal area (Rosa and Vieira, 2003).

For a long time, salt marshes had been seen as unpleasant areas; however, after the recognition of their ecological status, salt

\footnotetext{
* Corresponding author. Tel.: +351 234370 737; fax: +351 234370084

E-mail address: mvalega@ua.pt (M. Válega).
}

marshes became communities to preserve and to monitor. Environmental monitoring is essential to identify hazards to human health and also to assess environmental cleanup efforts to prevent further degradation of the ecosystems (Butterworth, 1995). The European Water Framework Directive (WFD) highlights the establishment of monitoring programmes to transitional and coastal waters in order to assess their ecological and chemical status.

According to Markert (2007), a bioindicator is an organism, a part of an organism or a society of organisms which gives information on the quality of its environment (qualitative information) and a biomonitor is an organism (part of an organism or a society of organisms) that quantifies the quality of its environment (quantitative information). The use of biomonitors has been increasing over the last years acting as a promising tool to identify potential hazards to human health and to provide new environmental quality assessment approaches (Butterworth, 1995; Ferrat et al., 2003; Melville and Pulkownik, 2006). Biomonitors have also been 
pointed out as important tools to assess geographical and/or temporal variations of the bioavailable fraction of the contaminants in the ecosystems (Rainbow and Phillips, 1993); in fact it is the bioavailable fraction that has more toxicological relevancy from the ecological point of view. The chemical analysis approach by itself may not be enough to predict the effects of a certain contaminant (the bioavailable fraction) on the living organisms and usually a complex set of speciation and fractionation studies are required. According to Zhou et al. (2008), the physico-chemical analysis can give detailed information about the metal species and contamination levels of the ecosystem while biomonitoring studies go further giving information about the bioaccumulation level and integrated toxicological effects. Metals are preferentially accumulated in the sediments but the bioavailable fraction is affected by its physico-chemical characteristics such as $\mathrm{pH}$, salinity, particle size and organic matter (Rainbow, 1995). The exposure of an organism to a contaminant is regulated by the amount of the contaminant but especially by its bioavailability and time of exposure (Powell, 1997).

The use of biomonitors in the field has several advantages since contaminants bioavailabilities are highly dependent on environmental conditions where abiotic and biotic factors are integrated. As already referred, metal availability and subsequent uptake is dependent on physico-chemical parameters of the sediment and since plants can modify the surrounding environment and consequently influence the bioavailable fraction, the bulk sediment analysis by itself may not measure the processes that may occur at the membrane surface where the changes occur (Powell, 1997).

Macrophytes have been suggested as bioindicators of metal contamination in coastal regions (Ferrat et al., 2003; Melville and Pulkownik, 2006). A good candidate as a biomonitor should obey a certain set of features such as a wide geographical distribution; to be easy to identify and sample; it should not be seasonal and it should be sufficiently long-lived, sedentary and available in such a reasonable size that could provide enough tissues for analysis and easy measurement of contaminants in their tissues without risk of approaching detection limits and contaminations issues (Rainbow, 1995).

Due to its high industrial value in the past, mercury was used in several industrial processes which led to its dispersion in the environment. Mercury is efficiently dispersed in the environment and in fact it is estimated that $80 \%$ of the mercury in the biosphere is due to anthropogenic sources (Mason et al., 1994). Once released in the environment, mercury does not degrade and even in small amounts biomagnifies through the food chain reaching dangerous levels in predatory fish (Wiener et al., 2003). Sediments are considered to be the principal depository for mercury (Sadiq, 1992) and despite reduction of anthropogenic emissions of mercury in the last decades resulting from the application of restriction rules, the mercury remaining in the sediments still is a concerning problem.

Plants have been used for biomonitoring processes giving a more time-integrated picture of the metal concentrations in the sedimentary compartment (Rainbow, 1995). There is evidence that plants may accumulate metals in their tissues (Weis and Weis, 2004; Válega et al., 2008a) and that rooted submerged macrophytes take up the bioavailable fraction of the metals from the sediments and interstitial waters. $H$. portulacoides (Caryophyllales: Chenopodiaceae) (common name: sea purslane) is a perennial salt marsh plant with a wide geographical distribution in the European salt marshes, being one of the most abundant (Bouchard et al., 1998; Caçador et al., 2007).

$H$. portulacoides presents a clear seasonal variation in its growing cycle, ranging between 978 and $1804 \mathrm{~g} \mathrm{DW} \mathrm{m}^{-2}$. Above ground biomass increased from late spring to early summer, and then gradually decreased until late winter (Válega et al., 2008b). The same pattern was observed in French salt marshes (Bouchard and Lefeuvre, 2000).

The aims of this study were: (i) to determine mercury concentrations in salt marsh sediments vegetated by $H$. portulacoides along the Portuguese coast; (ii) to evaluate mercury concentrations in the different organs of the plant; (iii) to evaluate the potential use of $H$. portulacoides as mercury biomonitor of salt marsh sediments. To achieve the above-mentioned objectives, $H$. portulacoides was sampled from North to South of Portugal in eight estuaries with different degrees of mercury contamination, and in each system two or more stations were assessed.

\section{Material and methods}

\subsection{Study areas}

This study was carried out along the coastal zone of Portugal (Fig. 1). Seventeen salt marsh stations from eight distinct estuarine systems were selected, namely, Cávado $\left(41^{\circ} 31^{\prime} \mathrm{N} 8^{\circ} 46^{\prime} \mathrm{W}-\mathrm{S} 1\right)$, Ria de Aveiro $\left(40^{\circ} 43^{\prime} \mathrm{N} \mathrm{8} 8^{\circ} 37^{\prime} \mathrm{W}\right.$ - S2; S3; S4; S5), Mondego $\left(40^{\circ} 07^{\prime} \mathrm{N}\right.$ $8^{\circ} 48^{\prime} \mathrm{W}$ - S6; S7), Tagus (38 $38^{\prime} \mathrm{N} 9^{\circ} 07^{\prime} \mathrm{W}$ - S8; S9; S10), Sado

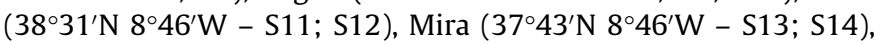
Ria Formosa $\left(37^{\circ} 00^{\prime} \mathrm{N} 7^{\circ} 58^{\prime} \mathrm{W}-\mathrm{S} 15 ; \mathrm{S} 16\right)$ and Guadiana estuary $\left(37^{\circ} 13^{\prime} \mathrm{N} 7^{\circ} 25^{\prime} \mathrm{W}-\mathrm{S} 17\right)$. With the exception of Mira (S13; S14) and Guadiana (S17), all stations are located nearby large urban areas and subjected to industrial, agricultural and fisheries activities. Cávado, Tagus and Sado are also subjected to harbour associated activities, like naval industry, and Ria de Aveiro and Tagus estuaries were in the past subjected to mercury contamination due to the presence of chlor-alkali plants.

\subsection{Sampling and analytical methods}

Sampling took place during late autumn and winter seasons (to exclude the growing season of the plants) and the samples were randomly collected in the salt marsh areas during low tide. Five replicates of sediments ( $15 \mathrm{~cm}$ depth) and plants biomass (below ground and above ground biomass) distanced by $15 \mathrm{~m}$ at least were always sampled. The sampled sediments were dried at $45^{\circ} \mathrm{C}$, homogenised and sieved $(1 \mathrm{~mm})$ in order to eliminate roots

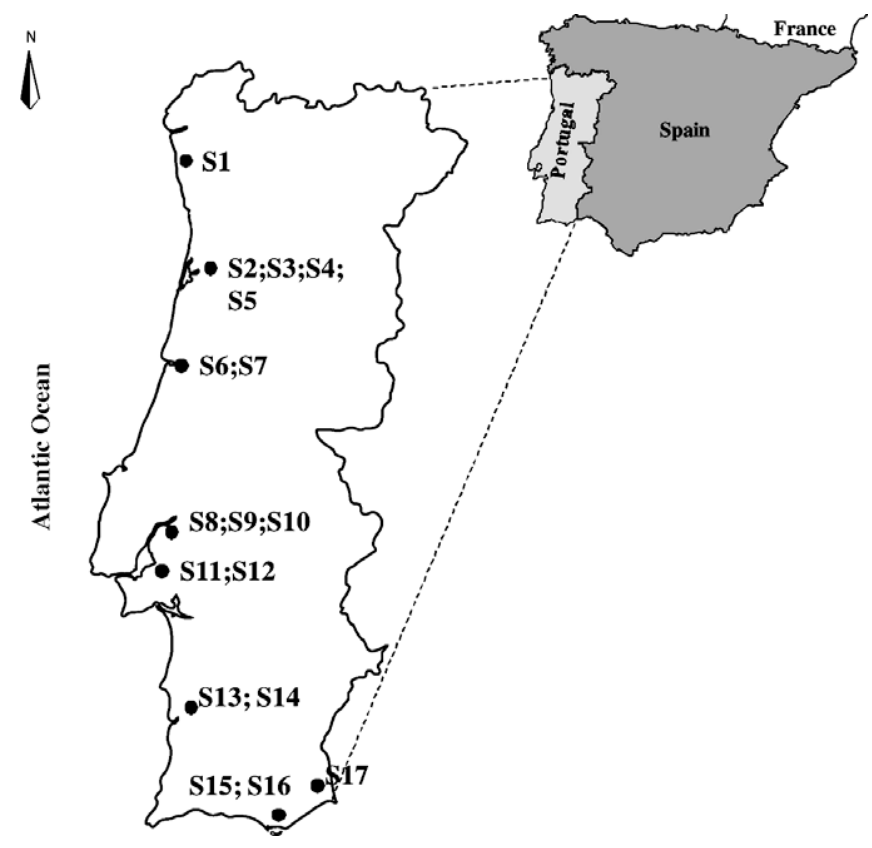

Fig. 1. Map of Portugal with the sampling stations. 
and debris. Roots were carefully separated from the sediment under a flux of water using a $250 \mu \mathrm{m}$ mesh size and rinsed with ultra-pure water to remove any adhering particles of sediments. Above ground biomass was also carefully rinsed with ultra-pure water and leaves and stems were separated. Any adhering material to the external surfaces like epiphytes was removed by moderate scraping. Biomass material was oven dried at $45^{\circ} \mathrm{C}$ and homogenised for further mercury determinations.

Mercury concentrations in sediments and biomass samples were determined by atomic absorption spectrometry with thermal decomposition of the sample (LECO AMA 254) according to Costley et al. (2000). This analytical methodology is simple and based on a thermal decomposition of the sample and collection of the mercury vapour on a gold amalgamator. The sample is first dried at $120^{\circ} \mathrm{C}$ prior to combustion at $680-700{ }^{\circ} \mathrm{C}$ in an oxygen atmosphere. The mercury vapour is collected in a gold amalgamator and after a pre-defined time ( $45 \mathrm{~s}$ ) the gold amalgamator is heated at $900{ }^{\circ} \mathrm{C}$. The released mercury is transported to a heated cuvette $\left(120^{\circ} \mathrm{C}\right)$ and then analysed by atomic absorption spectrometry (AAS) using a silicon UV diode detector. Operational conditions used included a drying time of $10 \mathrm{~s}$; decomposition time of $150 \mathrm{~s}$; waiting time of $45 \mathrm{~s}$ and the amount of samples used ranged between 50 and $500 \mathrm{mg}$.

The major advantage of using this technique is that it does not require complex manipulation of the sample, such as digestion processes, avoiding contaminations issues.

The precision of a method relies on the dispersion of the replicate results. In this work, each sample was always analysed at least in triplicate and the results rejected if the coefficients of variation (standard deviation/average ${ }^{*} 100$ ) were higher than $10 \%$. Accuracy of the results was achieved by the analysis of Certified Reference Materials (CRMs) PACS 2, MESS 3 (marine sediments for the sediments) and BCR 060 (trace elements in an aquatic plant for the plant biomass) every day at the beginning and at the end of the day. Certified and measured values were always in agreement with recoveries ranging between $92 \%$ and $95 \%, 100 \%$ and $110 \%$, and $90 \%$ and $100 \%$ for MESS 3, PACS 2 and BCR 60, respectively. Procedural blanks were carried out between samples to avoid cross contamination. Calibration was periodically checked using standard solutions, prepared from a $1000 \mathrm{mg} \mathrm{l}^{-1}$ mercuric nitrate standard solution $(\mathrm{BDH})$, diluted in ultra-pure water acidified with $\mathrm{HNO}_{3}$ ( $2 \% \mathrm{Hg}$-free).

\section{Results}

\subsection{Mercury concentrations in sediments}

Significant differences were found between the sampling stations $(p \leqslant 0.001)$. The range of mercury concentrations found in the salt marsh sediments along the Portuguese coast was high (Fig. 2). Mercury concentrations ranged between 0.03 and $17 \mu \mathrm{g} \mathrm{g}^{-1}$, with the highest concentrations found in four stations (S2; S3; S4; S5) of the Ria de Aveiro followed by one station located in the Tagus estuary (S8 - Rosario salt marsh). From the stations located in the Ria de Aveiro, it was possible to observe a gradient of metal contamination. Station 2 presented the highest values $\left(15.6 \pm 1.0 \mu \mathrm{g} \mathrm{g}^{-1}\right)$ while station 5 the lowest one $\left(1.9 \pm 0.1 \mu \mathrm{g} \mathrm{g}^{-1}\right)$. Station 3 and station 4 presented similar concentrations of mercury, $7.5 \pm 1.9$ and $7.7 \pm 0.4 \mu \mathrm{g} \mathrm{g}^{-1}$, respectively. These differences denote a contamination gradient according to the distance to the point source of mercury into the system, S2 being the closest and S5 the furthest as observed in a previous work (Válega et al., 2008c). In Tagus estuary, significant differences were observed between the three sampling stations although the mercury values found in Rosario (S8) and Corroios (S9) salt marshes were much

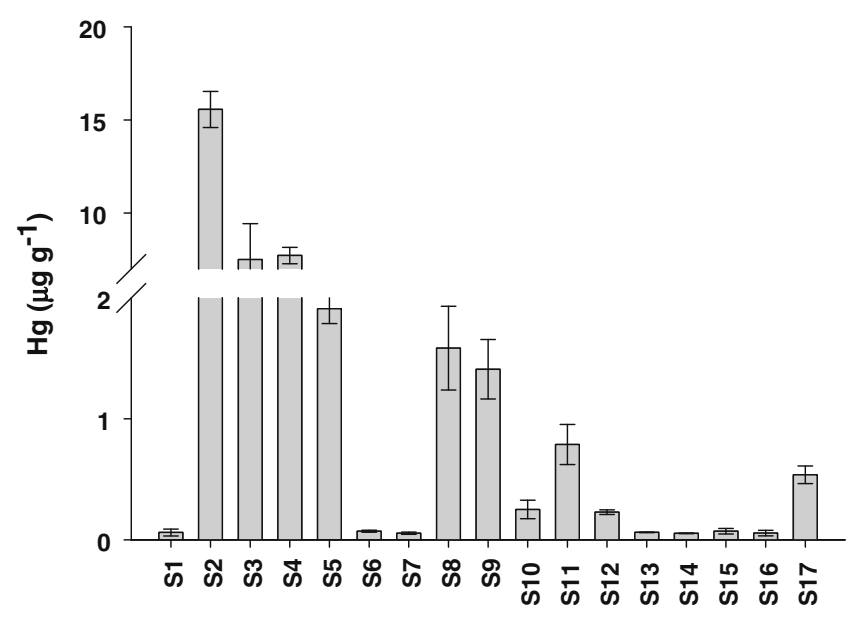

Fig. 2. Total mercury concentrations in the sediments ( $\mu \mathrm{g} \mathrm{g}^{-1} \pm$ stdev) colonised by H. portulacoides.

higher than those observed in the Hortas station (S10). The lowest mercury concentrations were found in Cávado, Mondego, Mira and Ria Formosa salt marshes. According to the Portuguese classification for mercury concentrations in dredged sediments, it was possible to identify different types of sediment classes along the Portuguese coast. The classification of sediments is made in classes from 1 to 5 regarding their degree of contamination: the least contaminated is classified as class $1\left(<0.5 \mu \mathrm{g} \mathrm{g}^{-1}\right)$, followed by class 2 $\left(0.5-1.5 \mu \mathrm{g} \mathrm{g}^{-1}\right)$, class $3\left(1.5-3.0 \mu \mathrm{g} \mathrm{g}^{-1}\right)$ and class 4 (3.0$\left.10 \mu \mathrm{g} \mathrm{g}^{-1}\right)$; the most contaminated is class $5\left(>10 \mu \mathrm{g} \mathrm{g}^{-1}\right)$. Most of the stations were classified as class 1 (S1; S6; S7; S10; S12; S13; S14; S15; S16), three as class 2 (S9; S11; S17), one as class 3 (S8), three as class 4 (S3; S4; S5) and only one station was classified as class 5 (S2). The values found in S2, S3 and S4 (7-17 $\left.\mu \mathrm{g} \mathrm{g}^{-1}\right)$ located in Ria de Aveiro can be considered extremely high and according to the Portuguese classification, it reveals that is an area requiring a special concern in order to avoid future environmental problems.

\subsection{Mercury concentrations in $H$. portulacoides}

Results concerning mercury accumulation in $H$. portulacoides showed that it occurs mainly in the roots. Mercury concentrations in the roots ranged between 0.01 and $12.9 \mu \mathrm{g} \mathrm{g}^{-1}$ (Fig. 3a), followed by the leaves, 0.009 and $0.12 \mu \mathrm{g} \mathrm{g}^{-1}$ (Fig. 3b) and stems, 0.002 and $0.056 \mu \mathrm{g} \mathrm{g}^{-1}$ (Fig. 3c). The highest values of mercury in the different organs of the plant were found in Ria de Aveiro and in one station of Tagus estuary ( 88 - Rosario salt marsh), as observed for the mercury concentrations in the sediments. A linear regression model was found to fit well the relations between the concentrations of mercury in the different plant organs and between the mercury concentrations in roots and stems (Fig. 4a, $R_{\mathrm{adj}}^{2}=0.75$ ), stems and leaves (Fig. $4 \mathrm{~b}, R_{\mathrm{adj}}^{2}=0.85$ ) and roots and leaves (Fig. 4c, $R_{\text {adj }}^{2}=0.78$ ).

\subsection{Mercury concentrations in the plant and in the surrounding sediments: $H$. portulacoides as a biomonitor}

In order to evaluate the response of $H$. portulacoides (roots and leaves) to mercury concentrations in sediments, a linear model and a sigmoidal model were tested and compared. The adjusted correlation coefficients $\left(R_{\mathrm{adj}}^{2}\right)$ were calculated between: (a) roots and sediments and between leaves and sediments, in order to find the model with the best fit to our data. All independent values were used for each station and not the mean values. The variation 

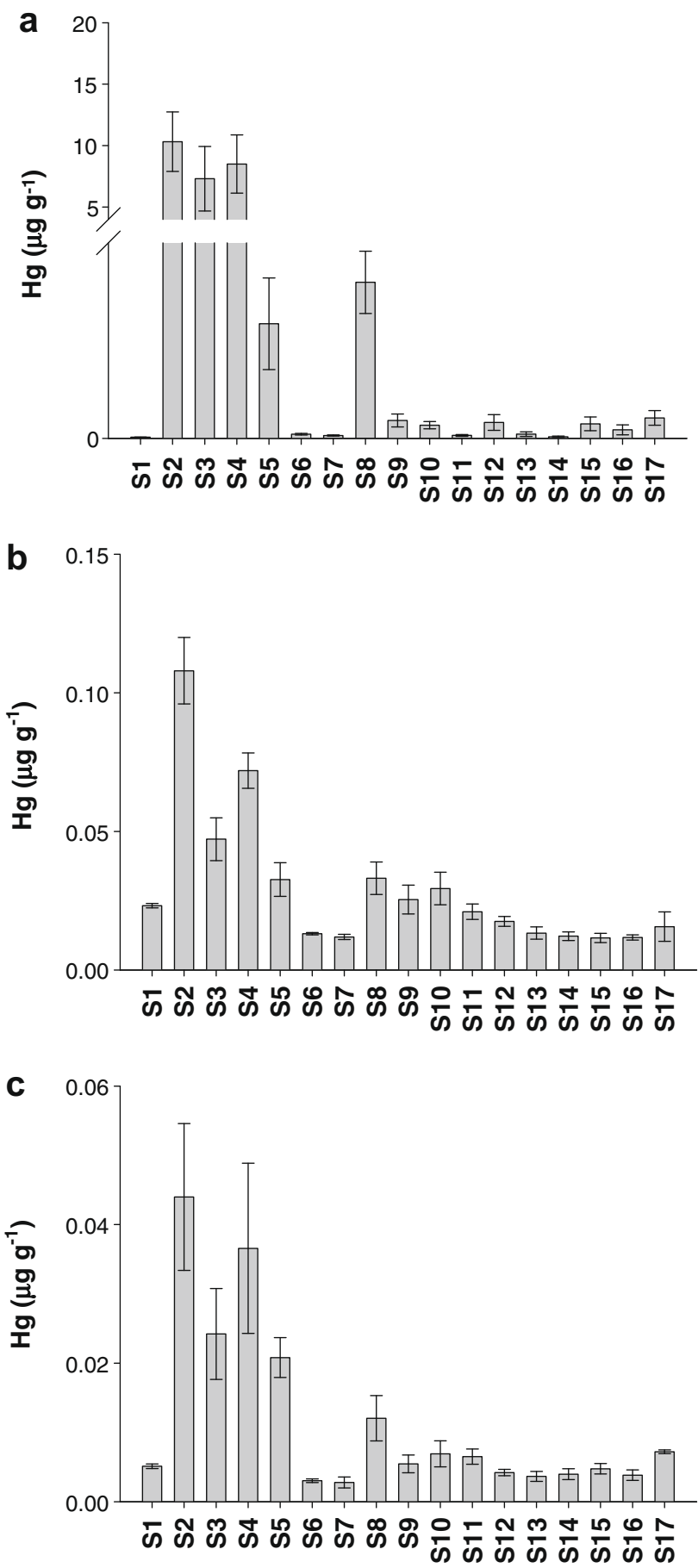

Fig. 3. Total mercury concentrations ( $\mu \mathrm{g} \mathrm{g}^{-1} \pm \mathrm{stdev}$ ) in the different organs of $H$. portulacoides (a) roots; (b) leaves; (c) stems.

of mercury concentration in the roots versus mercury concentration in the sediments was best fitted by a sigmoidal model equation (Fig. 5a, $R_{\mathrm{adj}}^{2}=0.89$ ).

As shown in Fig. 5a, mercury accumulation in the roots can be described in three steps: at a low range of mercury concentrations in the sediments (from 0.03 up to $2 \mu \mathrm{g} \mathrm{g}^{-1}$ ), the accumulation of mercury in roots is also low reaching a maximum concentration of $1.3 \mu \mathrm{g} \mathrm{g}^{-1}$; in a second step the rate of mercury accumulation in roots attains its maximum value until the concentration of mercury in sediments reaches approximately $4.5 \mu \mathrm{g} \mathrm{g}^{-1}$; after this maximum the accumulation of mercury in the roots slows down
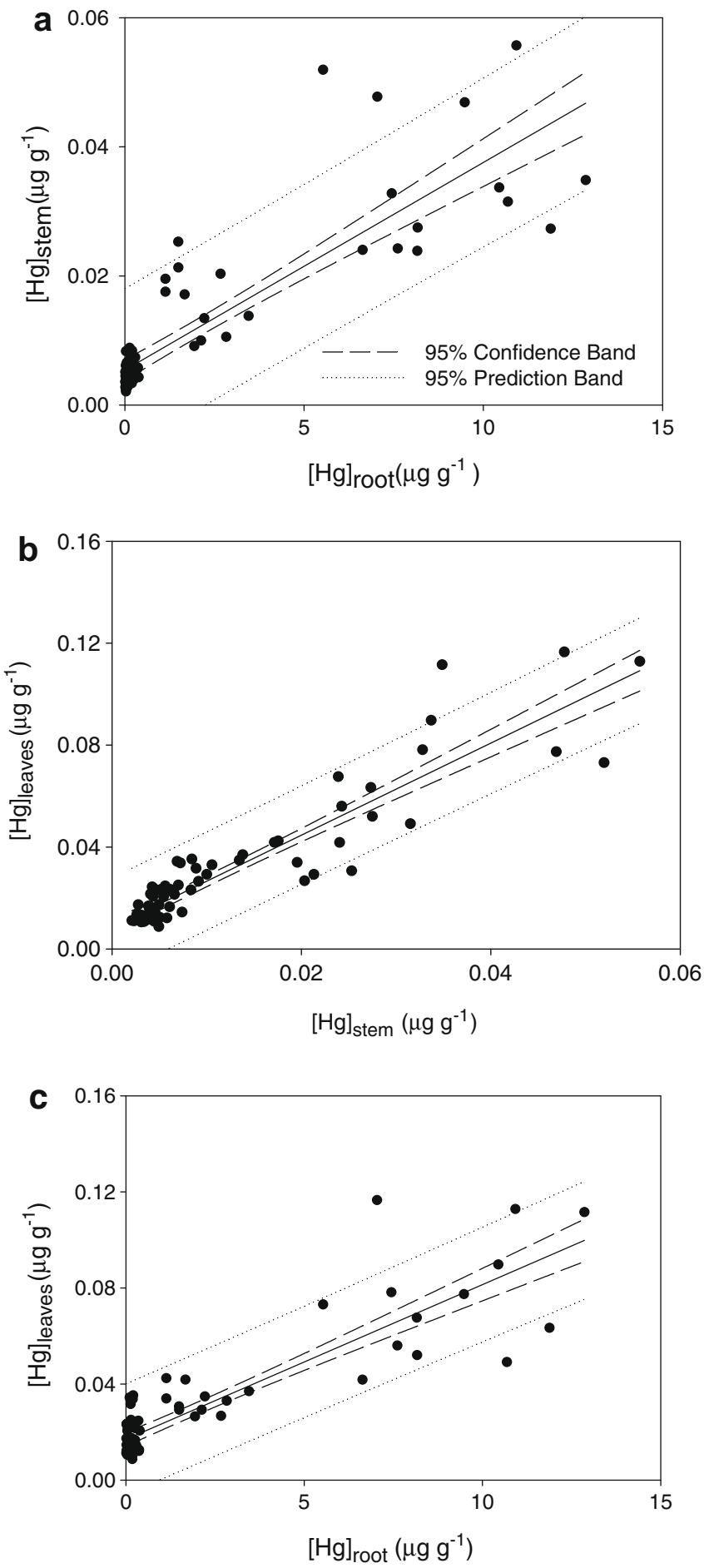

Fig. 4. Correlation coefficients of mercury concentrations between (a) roots and stems of $H$. portulacoides, (b) stems and leaves of $H$. portulacoides and (c) roots and leaves of $H$. portulacoides

leading to a plateau in the concentration of mercury in the roots of about $9.4 \mu \mathrm{g} \mathrm{g}^{-1}$, which corresponds to a concentration of mercury of about $11 \mu \mathrm{g} \mathrm{g}^{-1}$.

With respect to the relation between the mercury concentrations in leaves versus the concentrations in sediments, the best model explaining was the linear regression model $\left(R_{\mathrm{adj}}^{2}=0.88\right)$ as shown in Fig. 5b.

The ratios of mercury concentrations between the organs of the plant and sediments are indicative of the metal transfer from the 

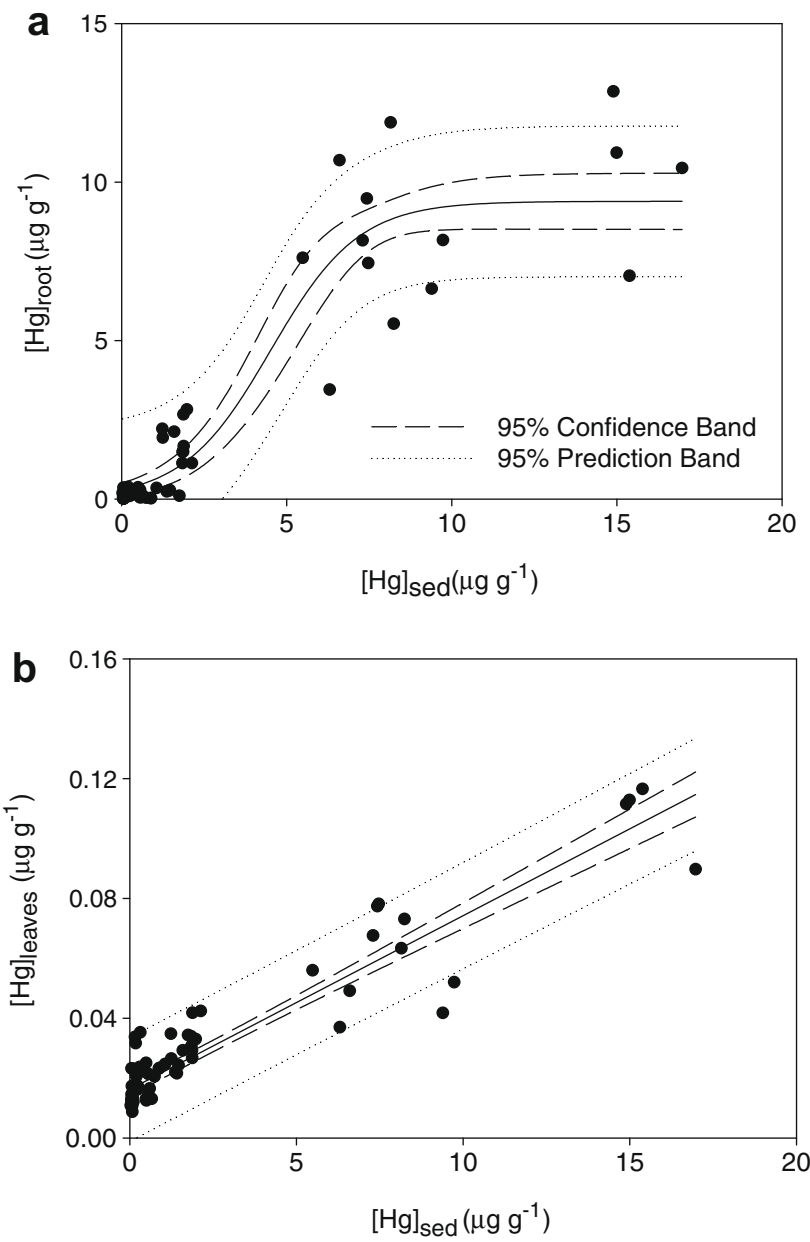

Fig. 5. Correlation coefficients of mercury concentrations between (a) sediments and roots of $H$. portulacoides, (b) leaves of $H$. portulacoides and sediments vegetated by $H$. portulacoides.

sediment to the plant and give information about the accumulation of the metal by the plant. Accumulation factors were calculated by the ratio between metal concentrations in roots and sediments as well between as roots and leaves and between leaves and stems (Table 1). H. portulacoides does not accumulate high amounts of mercury in the different organs. The bioaccumulation factor observed for the roots with respect to the sediments ranged between 0.1 and 2.2 (median value 0.8 ). Accumulation factors of mercury in the roots relatively to the leaves ranged between 0.7 and 152 (median value 12) which is an indicative of the low translocation of mercury inside the plant. Lowest differences were observed between the stems and the leaves; however higher accumulation factors were found in leaves ranging between 1.6 and 4.8 (median value 3.2).

\section{Discussion}

Mercury concentrations in the sediments clearly identify the Portuguese hotspots of mercury: the Ria de Aveiro and the Tagus estuary, due to chlor-alkali plant discharges in the past (Pereira et al., 1998; Canário et al., 2005). As mentioned by Covelli et al. (1999), marine sediments contaminated by industrial effluents can constitute a secondary source of mercury to the aquatic ecosystems even after the discharges have been ceased. The results show that sediments are the main compartment for mercury accumulation in salt marshes and represent the major reservoir of the
Table 1

Accumulation factors of mercury (average values for each station) for the different organs of $H$. portulacoides

\begin{tabular}{llll}
\hline Station & \multicolumn{2}{l}{ Accumulation factor } & \\
\cline { 2 - 4 } & Roots/sed & Roots/leaves & Leaves/stems \\
\hline S1 & 0.3 & 0.7 & 4.5 \\
S2 & 0.7 & 91.1 & 2.8 \\
S3 & 1.0 & 152.4 & 2.0 \\
S4 & 0.6 & 120.3 & 2.1 \\
S5 & 0.8 & 51.8 & 1.6 \\
S6 & 0.8 & 4.4 & 4.4 \\
S7 & 0.7 & 3.3 & 4.3 \\
S8 & 1.4 & 66.9 & 2.8 \\
S9 & 0.2 & 8.9 & 4.8 \\
S10 & 0.8 & 6.4 & 4.4 \\
S11 & 0.1 & 2.0 & 3.3 \\
S12 & 1.0 & 12.3 & 4.2 \\
S13 & 1.1 & 4.7 & 3.8 \\
S14 & 0.4 & 1.8 & 3.1 \\
S15 & 2.2 & 14.4 & 2.5 \\
S16 & 1.7 & 12.0 & 3.2 \\
S17 & 0.6 & 24.9 & 2.8 \\
\hline
\end{tabular}

metal. The highest levels of mercury contamination were observed in stations S2, S3 and S4 which are located in a confined area of Ria de Aveiro where several works have been reporting the contamination levels in the different compartments of the system (Abreu et al., 2000; Coelho et al., 2006; Ramalhosa et al., 2006; Válega et al., 2008a). Concerning mercury accumulation in $\mathrm{H}$. portulacoides, results showed that it occurs mainly in the roots which is also in agreement with observations for other salt marsh species (Weis and Weis, 2004; Válega et al., 2008a). The lower mercury accumulation in leaves is probably due to their constant renovation, while the lowest accumulation in stems is probably due to the fact that this organ is considered to be a transport organ for fluids and not a storage organ. The good correlations found between the stems and the leaves are an indicator that mercury concentrations in the leaves are probably due to translocation from the roots and not due to deposition of atmospheric mercury or absorption by the leaves during high tide. Nevertheless, the deposition process cannot be excluded but probably is not a major process.

Despite the fact that mercury concentrations in the organs (roots and leaves) of $H$. portucaloides increased with the increment of mercury in the sediments, two different response models were observed. Mercury concentrations in the roots versus the concentration in sediments followed a sigmoidal model. Similar to a calibration curve (imaging $H$. portulacoides roots as a biological sensor) at low concentrations, the accumulation in the roots is low and does not show a linear response, suggesting mechanisms of defence from the plant to avoid toxic concentrations. Above the concentration of $9.4 \mu \mathrm{g} \mathrm{g}^{-1}$, the concentration of mercury in the roots no longer increases with the increment of mercury in the sediments, showing a maximum constant response. This is probably due to the turnover rate of mercury between roots and the sediments. On the other hand, mercury concentrations in leaves versus the concentration at the rhizosphere followed a linear model. Differences in responses of roots and leaves are explained by the dynamics of the plant organs. Mercury accumulated in the below ground part of the plant is quite mobile and mostly returns to the sediment pool through the mineralisation process. According to Pereira et al. (2007), the decomposition of roots of $H$. portulacoides corresponded closely to $42-46 \%$ of mass lost (dry weigh) in the first months.

Due to the positive linear correlation coefficients between the mercury concentrations in roots, leaves and sediments, $H$. portulacoides can be suggested as a suitable biomonitor for mercury in salt marshes. However, the application of the model should be cautious and some aspects should be taken into account namely: the life 
cycle of the species, and the variability in environmental contamination. Explicitly, during the growing season results may be underestimated due to the fast increase in biomass which may promote a dilution in the effect on the accumulated mercury, while the spatial variability of the system should be taken into account during sampling procedure, especially in areas with a high level of contamination. On the other hand, although leaves showed higher correlation coefficients with mercury concentrations in sediments, roots should be preferred for environmental evaluation whenever atmospheric deposition of mercury is significant.

The results obtained in this work show that the sampling of salt marsh plants must be done carefully and a high number of field replicates are recommended in order to reflect the high spatial variability of these ecosystems. Coefficients of variation (standard deviation/average ${ }^{*} 100$ ) were calculated for the results in order to assess the spatial variability of each system. According to the results, it was possible to conclude that in some systems, independently of the degree of contamination, the spatial variability can be extremely high. In sediments the coefficients ranged from $4 \%$ to $31 \%$ while in roots the coefficients were found to vary between $20 \%$ and $54 \%$. Low values were found in the leaves (3-21\%) and stems (4-34\%). This variability can be related with the system variability caused by the dispersion of the contamination into the system and with the genetic variability of the plants besides their age.

An important advantage of this work is the fact that it is a field work. Laboratory tests have their limitations and the results are usually dependent on several variabilities including the test conditions which may be different from the natural conditions. Laboratory test tends to be more conservative and usually are performed in a short period of time (Powell, 1997).

\section{Conclusion}

As a main conclusion of the present work, $H$. portulacoides, previously described as a bioindicator, can also be used as a biomonitor for mercury contamination in salt marshes. Leaves responded following a linear model for a sediment contamination range between 0.03 and $17.0 \mu \mathrm{g} \mathrm{g}^{-1}$, while roots responded according to a sigmoidal model. Even though, the application of the models should take into consideration the life cycle of the plant, $\mathrm{H}$. portulacoides may be considered an appealing tool for mercury pollution assessment and evaluation in salt marsh ecosystems.

\section{Acknowledgements}

This research was supported by the Portuguese Science and Technology Foundation (FCT) through a PhD grant (SFRH/BD/ 18682/2004) funding M. Válega.

\section{References}

Abreu, S., Pereira, E., Vale, C., Duarte, C., 2000. Accumulation of mercury in sea bass from a contaminated lagoon (Ria de Aveiro, Portugal). Mar. Pollut. Bull. 40, 93297.

Alongi, D.M., 1997. Mangroves and salt marshes. In: Kennish, M.J., Lutz, P.L. (Eds.), Coastal Ecosystem Processes. CRC Press, Boca Raton, FL.
Bouchard, V., Creach, V., Lefeuvre, J.C., Bertru, G., Mariotti, A., 1998. Fate of plant detritus in a European salt marsh dominated by Atriplex portulacoides (L.). Aellen. Hydrobiologia 373 (374), 75-87.

Bouchard, V., Lefeuvre, J.C., 2000. Primary production and macro-detritus dynamics in a European salt marsh: Carbon and nitrogen budgets. Aquat. Bot. 67, 23-42.

Butterworth, F.M., 1995. Introduction to biomonitors and biomarkers as indicators of environmental change. In: Butterworth, F.M. et al. (Eds.), Biomonitors and Biomarkers as Indicators of Environmental Change: A Handbook. Plenum Press, New York.

Caçador, I., Tibério, S., Cabral, H., 2007. Species zonation in Corroios salt marsh in the Tagus estuary (Portugal) and its dynamics in the past fifty years. Hydrobiologia 587, 205-211.

Canário, J., Vale, C., Caetano, M., 2005. Distribution of monomethylmercury and mercury in surface sediments of the Tagus estuary (Portugal). Mar. Pollut. Bull. 50, 1142-1145.

Coelho, J.P., Rosa, M., Pereira, E., Duarte, A., Pardal, M.A., 2006. Pattern and annual rates of Scrobicularia plana mercury bioaccumulation in a human induced mercury gradient (Ria de Aveiro, Portugal). Estuar. Coast. Shelf Sci. 69, 629-635.

Costley, C., Mossop, K., Dean, J., Garden, L., Marshall, J., Carroll, J., 2000. Determination of mercury in environmental and biological samples using pyrolysis atomic absorption spectrometry with gold amalgamation. Anal. Chim. Acta 405, 179-183.

Covelli, S., Faganeli, J., Horvat, M., Brambati, A., 1999. Porewater distribution and benthic flux measurements of mercury and methylmercury in the Gulf of Trieste (Northern Adriatic Sea). Estuar. Coast. Shelf Sci. 48, 415-428.

Ferrat, L., Pergent-Martini, C., Roméo, M., 2003. Assessment of the use of biomarkers in aquatic plants for the evaluation of environmental quality: Application to sea grasses. Aquat. Toxicol. 65, 187-204.

Markert, B., 2007. Definitions and principles for bioindication and biomonitoring of trace metals in the environment. J. Trace Elem. Med. Bio. 21, 77-82.

Mason, R.P., Fitzgerald, W.F., Morel, F.M.M., 1994. The biogeochemical cycling of elemental mercury: Anthropogenic influences. Geochim. Cosmochim. Acta 58, 3191-3198.

Melville, F., Pulkownik, A., 2006. Investigation of mangrove macroalgae as bioindicators of estuarine contamination. Mar. Pollut. Bull. 52, 1260-1269.

Pereira, M.E., Duarte, A.C., Millward, G.E., Vale, C., Abreu, S.N., 1998. Tidal export of particulate mercury from the most contaminated area of Aveiro's lagoon, Portugal. Sci. Total Environ. 213, 157-163.

Pereira, P., Caçador, I., Vale, C., Caetano, M., Costa, A.L., 2007. Decomposition of belowground litter and metal dynamics in salt marshes (Tagus estuary, Portugal). Sci. Total Environ. 380 (1-3), 93-101.

Powell, R.L., 1997. The use of vascular plants as "field" monitors. In: Wang, W. et al. (Eds.), Plants for Environmental Studies. CRC Press Lewis publishers, Boca Rotan, FL, pp. 335-365.

Rainbow, P.S., Phillips, D.J.H., 1993. Cosmopolitan biomonitors of trace metals. Mar. Pollut. Bull. 26, 593-601.

Rainbow, P.S., 1995. Biomonitoring of heavy metal availability in the marine environment. Mar. Pollut. Bull. 31, 183-192.

Ramalhosa, E., Pato Monterroso, P., Pereira, E., Vale, C., Duarte, A.C., 2006. Accumulation versus remobilization of mercury in sediments of a contaminated lagoon. Mar. Pollut. Bull. 52, 353-356.

Rosa, M.J.V., Vieira, C., 2003. A população portuguesa no século XX - Análise dos Censos de 1900-2001. Instituto da Ciências sociais da Universidade de Lisboa (Eds.), Liboa.

Sadiq, M., 1992. Toxic Metal Chemistry in Marine Environments. Marcel Dekker, New York.

Válega, M., Lillebø, A.I., Pereira, M.E., Corns, W.T., Stockwell, P.B., Duarte, A.C., Pardal, M.A., 2008a. Assessment of methylmercury production in a temperate salt marsh (Ria de Aveiro Lagoon, Portugal). Mar. Pollut. Bull. 56, 136-162.

Válega, M., Lillebø, A.I., Caçador, I., Pereira, M.E., Duarte, A.C., Pardal, M.A., 2008b. Mercury mobility in a salt marsh colonised by Halimione portulacoides. Chemosphere 72, 1607-1613.

Válega, M., Lillebø, A.I., Pereira, M.E., Duarte, A.C., Pardal, M.A., 2008c. Long-term effects of mercury in a salt marsh: Hysteresis in the distribution of vegetation following recovery from contamination. Chemosphere 71, 765-772.

Wiener, J.G., Krabbenhoft, D.P., Heinza, G.H., Scheuhammer, A.M., 2003. Ecotoxicology of mercury. In: Hoffman, D.J., Hoffman, D.J., et al. (Eds.), Handbook of Ecotoxicology. CRC Press, Boca Raton, FL, pp. 409-463.

Weis, J.S., Weis, P., 2004. Metal uptake transport and release by wetland plants: Implication for phytoremediation and restoration. Environ. Int. 30, 685-700.

Zhou, Q., Zhang, J., Fu, J., Shi, J., Jiang, G., 2008. Biomonitoring: an appealing tool for assessment of metal pollution in the aquatic ecosystem. Anal. Chim. Acta. 606, 135-150. 